\title{
Good Preparation, Successful Outcomes
}

All involved in study abroad are acutely aware of the importance of better preparing the students prior to their departure to the foreign country, of helping them find their place in the new environment once they have arrived in the country, and giving them both academic and practical support during their experience abroad. Our Brown-in-France Program is no exception to this philosophy, as the case of Emily Kanstroom illustrates well. While not a research program per se, Brown in France actively helps students to pursue independent research projects alongside more traditional academic courses.

Before coming to study in Paris at the Institut d'Etudes Politiques (SciencesPo) for one semester in 2004, Emily had already accomplished much in terms of her French studies at the university level: she completed the language sequence during her first year on campus (our minimum requirement to apply for study in France), and went on to take three more classes in advanced French, including a one-semester intensive conversation and culture course that we encourage all of our departing students to take. While the exact topic of the course changes from semester to semester, we always try to stress intercultural aspects through a variety of means ranging from the use of the "Cultura" methodology in tandem with a French school, or an intensive course on contemporary French culture and thought. ${ }^{1}$ In these courses, communicative and reasoning skills are at the center of the student's experience. Emily had also prepared herself in her chosen field of study by taking a vast array of Political Science, History and International Relations courses, and therefore was quite ready to tackle Sciences-Po for one semester.

Upon arrival in Paris, all Brown-in-France students go through a four-week orientation program designed to help them settle in both physically and practically, as well as intellectually and culturally. While the first week is devoted to resolving important practical problems such as securing an apartment ${ }^{2}$, getting a cell phone and opening a bank account, we quickly move into the content part of the orientation: French language training is a large part of orientation, and we accomplish this in a variety of ways that include guided tours, attending plays, readings, following the daily press, conversation classes, etc.. The language of communication and

\footnotetext{
${ }^{1}$ Cultura was developed at MIT by Gilberte Furstenberg (MIT), Sabine Levet (Brandeis) and Shoggy Waryn (Brown). It has now been adopted by other schools and adapted for use in other languages. For more information, see http://web.mit.edu/french/culturaNEH.

${ }^{2}$ The tendency has been for the past few years for students to elect to live on their own in a studio or small apartment and the demand for family-stay has decreased. We do not offer the option of staying in a dorm with other students.
} 
conversation at the office, and indeed during the entire stay, is always French.

Another important component is the cultural and academic aspect. While France may look and feel a little bit like home, the real cultural differences that lurk underneath the surface can sometimes be difficult to analyze or even accept. One of the strategies we use is the "Local" method (Listen, Observe, Compare, Analyze, Learn), where students are asked to actively pay attention to their surroundings (conversation in cafés, small talk in a shop, daily life interactions, etc.) and turn themselves into cultural investigators. They keep a journal of their observations and, with the help of a teacher, try to understand their reactions to the situations to which they were exposed and the lessons they learned. Finally, a large part of the orientation is devoted to preparing the students for the French university system and its specific methodology, which is in many ways quite different from what they are used to.

Emily had elected to attend Sciences-Po, and the course selections she made clearly influenced her article: "Globalization", "Political Institutions", "Shifts in Current Ideologies." She put to great use all the resources at her disposal, through our program, our tutoring system and the partner school in Paris. In particular, she met a professor at Sciences-Po who served as her mentor during her thesis project that was completed the following year. This mentor suggested possible subjects of interviews, appropriate archives and relevant places to visit that would be included in the final version of the paper.

Sciences-Po offered a basis for research which the open structure of our Paris program strongly fosters by having students make direct contact with French subject specialists. The program also encourages students to seek contacts outside of the Brown community, while our tutors facilitate this process by encouraging independent research on smaller topics and papers. Another form of assistance is the linguistic and cultural support provided throughout the semester by the entire staff of the program both in Paris and back in the US For example, I reread the translations that were to be included in the final paper the following year while teaching back at Brown in Providence, RI.

As a program for undergraduates, Brown-in-France's primary mission is to provide tools for successful learning, inside and outside the various universities with whom we have partnered. An essential component of the success of the program is to allow motivated students to pursue independent research in the field of their choice and to provide them with all the support they need.

\section{Shoggy Thierry Waryn, Ph.D. Resident Program Director, Brown Program In France}

